\title{
Eliminating Bottlenecks in the South African Conveyancing Environment
}

\author{
Anthea P Amadi-Echendu \\ Department of Business Management, University of South Africa \\ amadiap@unisa.ac.za
}

Prof René Pellissier

Graduate School of Business Leadership, University of South Africa pellir@unisa.ac.za

\section{Doi:10.5901/mjss.2014.v5n14p97}

\section{Abstract}

Customer valuations are not just about service quality but also process efficiency. As a result organisations need to continuously reassess their business processes in order to improve their operations and service delivery to their customers. Conveyancing deals with the exchange of immovable property. Although conveyancing processes are wider in context than conventional organisational-level business processes, the issues of process bottlenecks, efficiency, and effectiveness are also present. The end-to-end property process in South Africa seems to be tedious, cumbersome and very complex. This paper deals with bottlenecks that may occur at the various stages in immovable property exchange transactions. It puts forward delay reasons identified by stakeholders in the property service chain and puts together a debottlenecking framework for the end-toend conveyancing process.

Keywords: Conveyancing, electronic processes, digitisation of data, bottlenecks

\section{Introduction}

Customer evaluations are not just about service quality but also about process efficiency (Samson \& Spring 2012). This judgement is often based not only on how long it takes an organisation to complete their function but also how effectively they use their resources. This calls for continuous changes and adjustments in order to improve performance which leads to higher productivity (Kaur, Singh \& Ahuja 2013).

Processes are used to execute an organisation's operations and other functions. Each process contributes to fulfilling customer expectations. The lean approach is founded on a smooth flow of processes and operations by doing the simple things well, continuously improving processes and eliminating waste (Pycraft, Singh, Phihlela, Slack, Chambers \& Johnston 2010:435). Any bottleneck will invariably disrupt the smooth flow of the process. It is therefore important to recognise possible capacity constraints within a process. The theory of constraints (TOC) has been developed to look at bottlenecks within an operation. It is an approach that seeks to improve quality and performance which will meet or exceed customer expectations (Kaur et al 2013). It is a long-term success strategy for organisations. By identifying the location of constraints, working to remove them, and then anticipating the next constraint, an operation is always focused on what determines the pace of output (Slack, Chambers \& Johnston 2010:449). Externally higher quality improves customer satisfaction which in turn increases customer loyalty which in turn results in higher profits and increased market share (Kaur et al 2013).

Conveyancing deals with the exchange of immovable property. The main point here is that, although conveyancing processes are wider in context than conventional organisational-level business processes (Winter \& Knemeyer 2012), however, the issues of process bottlenecks, efficiency, and effectiveness also prevail, and generally manifest in terms of cumbersome and tedious delays in the transfer of landed property from one owner to another. The success of organisations in managing their supply chains depend largely on the entity's efficiency in managing its processes (Loke, Downe, Sambasivan \& Khalid 2011).

The identification of a bottleneck is a critical aspect of process analysis as it determines the process capacity but also provides an opportunity to enhance that capacity. A bottleneck is any step whose capacity is equal to or less than the demand placed upon it. The results or throughput of a process can only be improved by alleviating the bottleneck (Groznik 2012). Improving other steps besides the bottleneck will not improve the system output. Saving time in a 
bottleneck will save time for the entire process. This can be done in a number of ways, such as increasing resources at the bottleneck activity, standardising, incorporating lean principles, etc. The efficiency of a process can be greatly improved if bottlenecks can be alleviated by shifting work without increasing costs, although it may be more difficult to do where specialised job functions are applicable (Roghanian, Rasli \& Gheysari 2012). High operational efficiency is dependent on quick, accurate and continuous exchange of information between organisations as well as within organisations (Groznik 2012).

South African conveyancing processes gives the impression that it takes too long for property exchange to be effected in South Africa. This leads to the main research statement that the conveyancing processes in South Africa involve cumbersome (difficult to use or deal with because of length or complexity), tedious (continuing for too long) and complex (made up of many interrelated parts) transactions. The associated questions lead to a search into how the transactions can be improved. That is, how can the transactions become more efficient and effective? To identify bottlenecks within the South African conveyancing processes will involve an investigation into the various factors that play a role in the conveyancing process to identify where the delays occur. Gordon, Nell \& Bertoldi (2007) illustrate that some transactions can take from two to six months to complete because of the cumbersome and tedious interaction between the associated role players.

In some cases, the transactions that are included in a single property exchange may involve several different attorney firms, each representing a role player, and each of them will be required to lodge their respective documents at the Deeds Office Registry. Where more than one property is involved, the transactions may be linked to even more role players; therefore, it is not uncommon for the entire conveyancing process to comprise of more than a hundred transactions before completion of the property exchange. The process tends to be exacerbated where the transactions involve manual interlinks and information transfer loops between the various role players.

The purpose of this research was therefore to develop a conceptual framework to improve conveyancing processes in SA. This was done by investigating the various processes involved in conveyancing and identifying the measures that could improve the overall conveyancing process. Reduction in processing times could lead to lower fees for customers and faster registrations.

This paper uses the theories of Total Quality Management and Bottlenecks to illustrate the system constraints identified in the end-to-end conveyancing process. It further develops a framework to deal with bottlenecks identified in the conveyancing environment.

\section{The Property Process in South Africa}

Conveyancing is the legal transfer of property from one owner to another. The parties and role players in a typical conveyancing process generally include estate agents, sellers, buyers, conveyancers, financial institutions, and government agencies, such as the Deeds Office Registry, Internal Revenue Service (IRS), and local and municipal authorities (Ramwell, Brink \& West, 2008:3). Where an estate of a deceased person is the seller, the Master may also be a role player. Depending on the roles and responsibilities of the various parties involved, a typical conveyancing interaction can involve many, and very complex transactions.

In South Africa, the deed registration is conducted by the Department of Land Affairs through its ten Deeds Offices under the supervision of the Chief Registrar of Deeds. The South African land registration is based on statute and is nominally based on characteristics of a positive and negative land registration system (Ramwell et al., 2008) thus making the South African system completely unique. Although the SA Deeds Office does not guarantee the correctness of a title (negative system) in the form of a state guarantee, third parties do rely on the accuracy of the legal position of real rights registered with regard to immovable property. The land register is linked to a cadastral (i.e. a system of maps) which is an aspect of a positive land system. In South Africa, land registration is based on statute (i.e. the Deeds Registry Act and the Alienation of Land Act). The security of title that South African titleholders enjoy is not the result of a State Guarantee (as with a positive system), but a private-public partnership between the Deeds Office and the conveyancing profession.

The conveyancing process begins with a seller who has a property to sell. An estate agent may assist the seller to market the property to prospective buyers. A different estate agent may introduce prospective buyers to the property. A buyer interested in purchasing the property will complete an offer to purchase which is then accepted by the seller by means of a signature on the same offer to purchase document. The offer to purchase is a legal contract which contains all the relevant details of the property, such as the property description, selling price, and commission payable to the estate agent, as well as the terms under which the sale agreement is concluded. The buyer may either purchase the property by paying for it in cash, or may use proceeds from investments, loans from family and/or friends, or apply for a loan from a financial institution. In SA, mortgage originators assist buyers to apply to banks for financing. 
Financial institutions normally take responsibility for managing functions across the entire conveyancing service chain, as banks only start earning an income after the property transfer has been finalised. They provide feedback to estate agents and mortgage originators regarding the progress of the loan application, and thereafter follow up with conveyancers regarding the registration of the new title. In fact, in South Africa, service level agreements are drawn up with conveyancers to ensure that registration takes place within certain specified timeframes and that security documentation is delivered to banks within a specified timeframe after the transfer of title has taken place. The work allocated to conveyancers is dependent on the conveyancer's ability to affect property transfers within the banks' required timelines (Amadi-Echendu, 2013). Figure 1 below provides an overview of all the role players involved in the conveyancing process.

\section{Property Stakeholders}

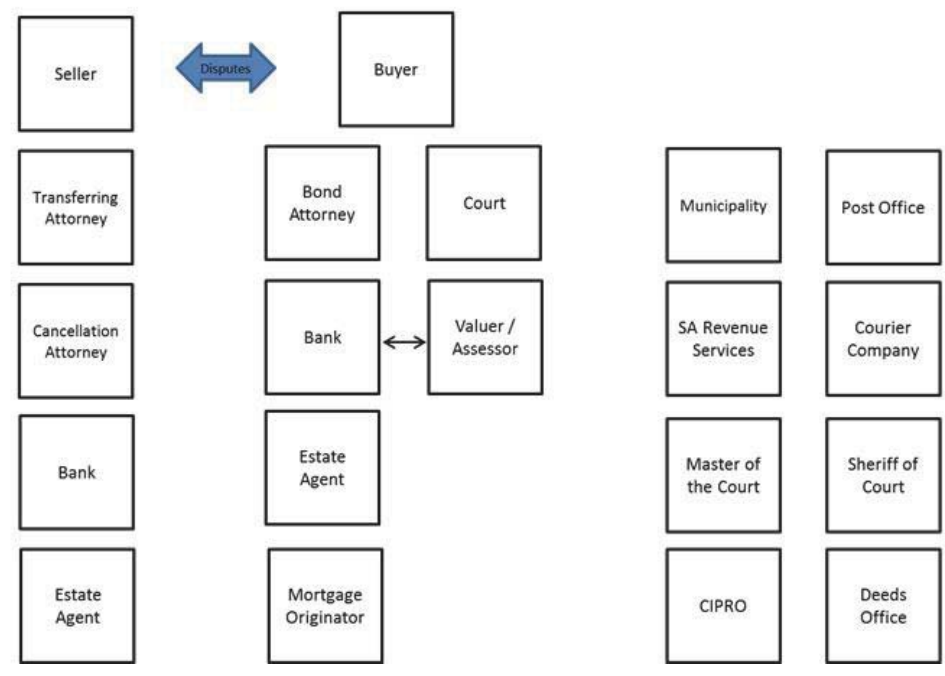

Figure 1: The role players involved in property exchange in South Africa

\section{Research Methodology}

Both qualitative and quantitative approaches were used in this study. A purposive sample was used in this study and the respondent groups for the surveys were drawn from a sample population that included estate agents, sellers, buyers, conveyancers, financial institutions, attorney firms mortgage originators and government agencies within South Africa, who are (or have been) involved in property exchange over the last five years. It was assumed that the transactions occurring between the selected role players is significantly valid for the interviews. Because of their size, there are likely to be many more transactions and types of transactions occurring amongst the bigger role players. Qualitative interviews were conducted with the Estate Agency Affairs Board, The Services Seta, two major banks in South Africa and a mortgage originator.

Quantitative questionnaires were distributed to banks, estate agents, buyers, sellers, mortgage originators and conveyancers. The options were divided into five Likert scales which the respondents had to choose from. All of the questions were mandatory, except for the questions that pertained to financing, as some of the immovable property could have been purchased for cash. The questionnaires were administered to a few respondents first to test the scale dimensions and the reliability of the components, before they were sent to the bigger sample. The first part of the questionnaire requested basic biometric data in order to meaningfully compare the information during analysis. The respondent names however will remain confidential. The rest of the questionnaire consisted of questions that pertain to the conveyancing process in general. The questions aimed at measuring the time linked to various steps in the process and to identify where the bottlenecks are in the process. Some of the questions required the respondents to rank the importance of the difficulty or occurrence of the problems. This helped to identify the extent of the difficulties experienced. 
Only role players that have been directly involved with the conveyancing process in the last five years were suitable for this study. One of the four major banks in SA distributed the conveyancing questionnaire to 200 conveyancers who are on their panel of attorneys. About 100 buyers and sellers each were approached to complete a questionnaire. Only the bigger estate agencies and mortgage originators that have a national footprint were approached, as the number of transactions that occur with these entities would be significantly valid. Although these samples are significantly small when compared to the entire population, the results are deemed to be significantly valid for the purposes of this study.

Two of the four major banks in SA were interviewed - the other two banks did not consent to participate in the study. In Phase 1 personal telephonic and personal interviews were conducted with knowledgeable persons in The Netherlands. These candidates were located via the internet while others were referrals from potential candidates located via the internet. The telephonic interviews were not structured and mainly aimed to understand the conveyancing process. In addition face-to-face interviews were conducted with a notary, estate agent and mortgage originator in The Hague, The Netherlands.

Phase 2 consisted of personal interviews that were conducted with a knowledgeable person in two of the four major lending banks in South Africa. These people were located by telephonically contacting the national home loan offices of the four major lending banks. The local interviews were conducted by means of a structured questionnaire. A copy of the quantitative questionnaire and interview questions were sent to each respondent before the interview to allow each person to adequately prepare for the interview and to remove all elements of surprise. Banks are extremely competitive and it was important for each bank to understand and see that the questions were not intrusive. The main aim of the interviews was to extract qualitative data from the interviewees in order to determine what they perceived to be the bottlenecks in the conveyancing end-to-end process. The interviewees' names will, however, remain confidential.

Published information, to identify issues and extract factors that influence conveyancing processes in general and in other countries were also used. The main sources included relevant articles in journals or accessed from the Internet, as well as papers that were delivered at conferences. The main objective of the literature study was to identify conveyancing steps of the conveyancing processes in The Netherlands.

\section{Findings and Implications}

Data from the respondents were captured and prepared for analysis by entering it into the Lime survey. The raw data were then transformed into variables and codes that were used in the analyses. Descriptive statistics were used to describe the features of the quantitative data in the study. The Statistical Package for the Social Sciences (SPSS) was used to perform and calculate all the statistical procedures. The reliability and validity of measures taken during the research reflect the level of confidence one can have in the results yielded by the research design. They determine whether results can be generalised to a population (Page \& Meyer 2006:84). A reliability analysis was not conducted as some of the sample sizes were too small for some entities, for example, Banks had eight respondents. Not all of the 17 banks registered with the Reserve Bank are involved with mortgage loans, and two of the four major banks did not consent to participate in the study. The questionnaire was also not structured to measure constructs or dimensions. The items or questions are independent and they measure different aspects.

The content of the interviews were taped and transformed into field notes. Content analysis was used to analyse the qualitative data received from the interviews. This was done by identifying key points or themes. The quantitative information that was obtained from the interviews was analysed using content analysis. The quantitative data from the respondents were captured and prepared for analysis by entering it into the Lime survey. The raw data were then transformed into variables and codes that were used in the analyses. Descriptive statistics were used to describe the features of the quantitative data in the study. The Statistical Package for the Social Sciences (SPSS) was used to perform and calculate all the statistical procedures.

Figure 2 below sets out delay reasons that have been put forward by the different respondent groups of the questionnaires and interviews. These delay reasons play out in the capacities of all the different role players involved in the end-to-end conveyancing process, whether intentional or not. 


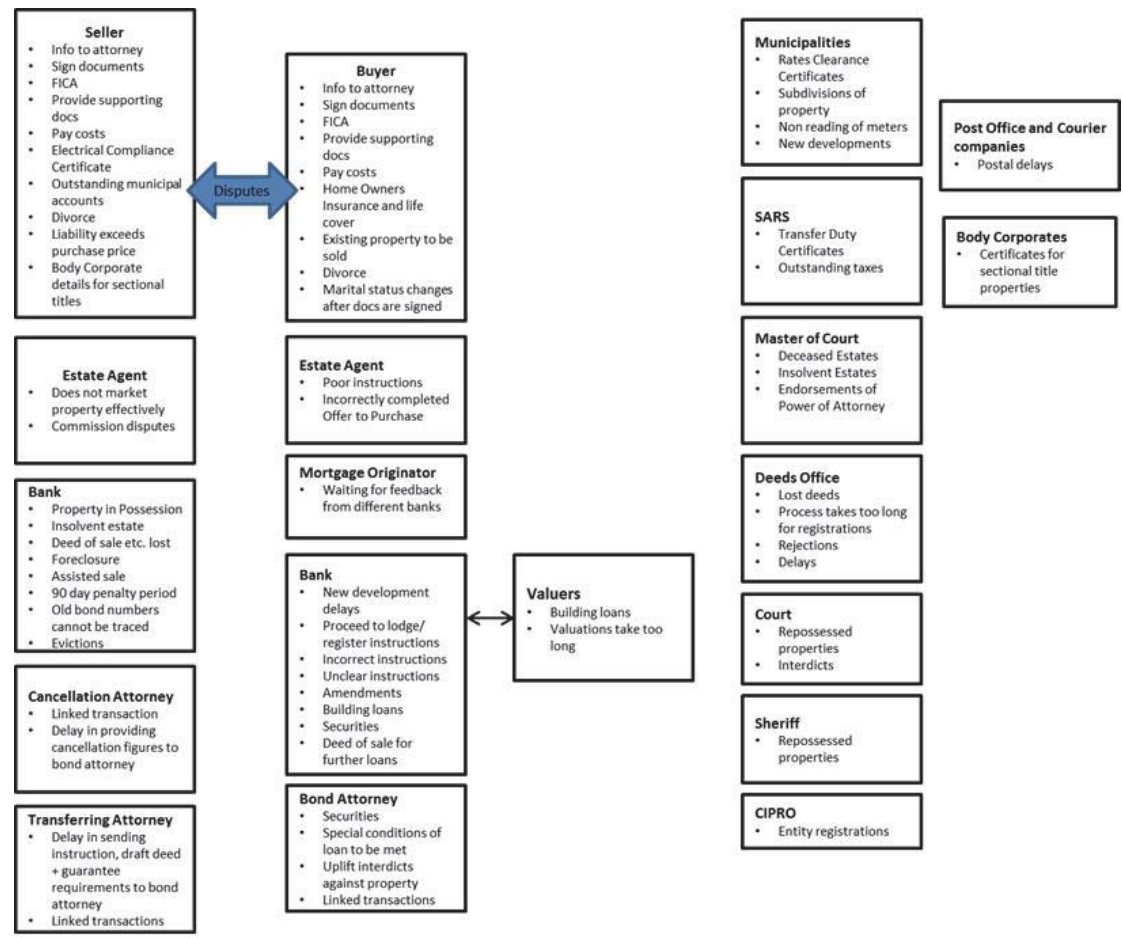

Figure 2: Bottlenecks in the SA conveyancing processes

Figure 2 illustrates that bottlenecks occur throughout the end-to-end conveyancing process. It is clear that each entity manages their own processes only, with little regard for the processes of others, unless those actions or processes are regulated by a service level agreement. The interviews also confirmed numerous delays, such as municipal clearance certificates, estate transfers via the Master of the Court, insolvency transfers and new developments that need to be proclaimed as a new township by the Municipality in that region. The following Figure 3 sets out the delay reasons as they occur among the different role players. They have been grouped under main headings for ease of reference.

\section{Debottlenecking framework}

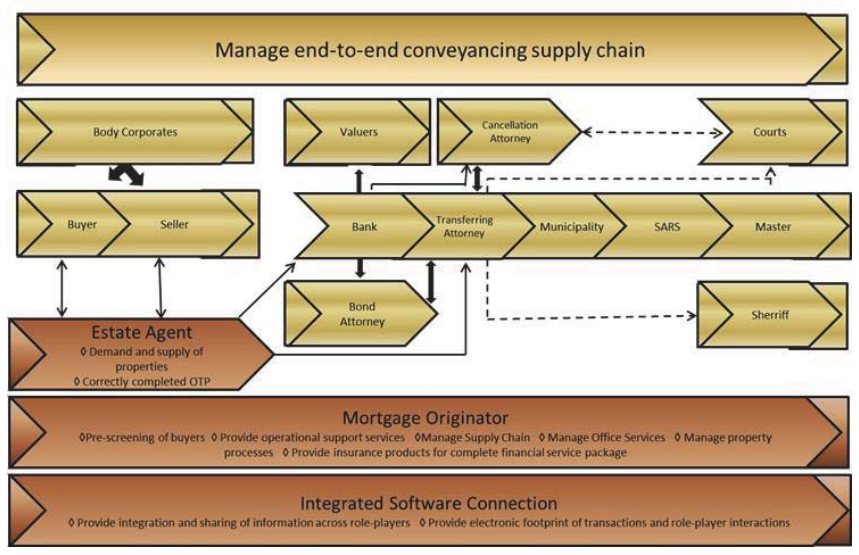

Figure 3: Conceptual model for improving conveyancing processes in the South Africa 
It is clear that each entity manages their own processes only, with little regard for the processes of others, unless those actions or processes are regulated by a service level agreement. According to the questionnaire responses, the majority of transactions register within three months from the time of submission. A study into the conveyancing process in the Netherlands revealed that mortgage originators plays a role from the beginning of the conveyancing process where a buyer identifies a property to purchase, up to the point of registration of this property in favour of the buyer. The accountability of the mortgage originator is also increased by means of statutory regulation. Different levels of training and assessment allow for the selling of specific product types by these agents in the Netherlands. In SA, the Estate Agency Affairs Board (EAAB) has embarked on rolling out such an initiative for estate agents. Perhaps the same type of regulation and training in the mortgage origination arena would be of value in SA.

It is also clear that service level agreements are used by banks in SA to control the actions and processes of the role players that they interact with in the conveyancing end-to-end process (interviews 2013). Taking into account the role that mortgage originators play in the property process in The Netherlands, it seems appropriate to propose that the mortgage originators in SA take accountability for managing the property transactions throughout the property service chain until property transfer of ownership has been completed by means of registration in the Deeds Office. However, mortgage originators are not regulated by a professional body in SA. This may have to be investigated and rectified and the scope of their roles and functions should be outlined, clarified and documented.

Furthermore, the introduction of integrated electronic systems to increase transparency in the process to all stakeholders involved is a further recommendation. In interfaced system will assist to share common information among the various stakeholders, increase communication exchanges as well as decrease common errors by different role players across the property value chain. It will further leave an electronic footprint which could enhance the security of transactions if proper encryption and electronic signatures are introduced. With increased transparency in the end-to end service chain, the turnaround time of transactions are bound to improve as well.

\section{Implications to Complexity, Cumbersomeness and Tediousness of Landed Property Transfers and the Impact on Business Operations}

The problem statement of this study indicated that preliminary evidence suggested that conveyancing in South Africa is complex (i.e. made up of many interrelated parts), cumbersome (i.e. difficult to use or deal with because of length or complexity and various stakeholders that are involved in the process) and tedious (i.e. continuing for too long) [The Free Dictionary, n.d, Kernerman English Multilingual Dictionary 2006-2013, Merriam-Webster.com. Merriam-Webster, n.d).

During the data gathering process, the following aspects were grouped under 'complexity' as a theme: compliance, the impact of legislation, supply chain dependencies, process inefficiencies, benchmarking and competition. Service level agreements and mandates are used to manage processes across different role players in the end-to-end conveyancing process. Much effort and emphasis is placed on these aspects and reward and recognition strategies have also been linked to performance in terms of service level agreements and mandates. This forces role players to comply with these agreements and results in competition between role players, especially if they operate on the same playing field. It is interesting to note that benchmarking was only mentioned by the Estate Agency Board. This gives the impression that all the other role players are more internally focused and they do not necessarily take learning from other countries or entities that appear to be more successful.

The following aspects were linked to 'cumbersomeness' as a theme: fraud, process risk, process inefficiencies and knowledge. Many additional processes have been put into place, predominantly by banks, to try and curb fraudulent activities. The use of ultraviolet lights in attorney offices to validate identity documents has been made mandatory by one of the major banks in SA. These additional processes have a time and cost implication for banks and attorneys. This process becomes even more cumbersome where non-individual entities are involved. Process risk refers to those activities where an oversight may result in errors that can have financial implications for various role players, as well as delays and other associated frustrations. It also is indicative of strict control and high bureaucracy - 'we run a tight team here...' (Amadi-Echendu, 2013). The level of expertise in the industry should be able to interpret information correctly and assist the buyers without undue errors that result in delays - this is also noted by different role players. The estate agent industry is also implementing an accreditation process whereby estate agents will not be recognised by the industry unless they comply with stated requirements by a certain date.

Turnaround time and delays were grouped under 'tediousness' as a theme. Turnaround time has been incorporated into the service level agreements administered to particularly attorneys. Figure 2 set out the various delays that can occur across the end-to-end conveyancing process. The delays occur in different areas and are caused by different role players across the property service chain. 


\section{Conclusion}

This study investigated the conveyancing process in SA. Literature, quantitative questionnaires and qualitative interviews were used to identify bottlenecks that occur across the end-to-end property process in SA. The impact was assessed in terms of the literature, qualitative surveys and qualitative interviews that were used to gather data. The research objective was to investigate the SA conveyancing systems with a focus on how to improve the efficiency and effectiveness of conveyancing processes, so that the SA context can adhere to global practices. A framework to improve the SA conveyancing end-to-end process was developed, based on delay reasons put forward by the various respondent groups. The framework suggests that mortgage originators should be regulated and their roles and responsibilities formalised in terms of legislation and code of conduct regulations. It is further suggested that their role be expanded to take ownership of the entire end-to-end administration, as well as additional financial and additional insurance responsibilities. This would, of course, imply further specialised training and accreditation for mortgage originators.

This study could be useful in assessing how to improve the current end-to-end conveyancing process in South Africa. Not much previous academic research and literature is available on conveyancing as a business concept. As a result, this study could become the basis of further study in this regard.

\section{References}

Amadi-Echendu A. 2013. The conveyancing process in SA. (Interviews: June 2013, Johannesburg; audio recording of interview in possession of researcher; Two major banks in SA. Identity withheld for security reasons).

Gordon R, Nell M \& Bertoldi A. 2007. Overview of urban land as a commodity in South Africa: research findings and recommendations. Report submitted to Matthewed Nell and Associates. June.

Groznik A \& Maslaric M. 2012. A process approach to distribution channel reengineering, Journal of Enterprise Information Management, Vol 25 Iss:2, pp. 123-135.

Kaur M, Singh K \& Ahuja IS. 2013. An evaluation of the synergic implementation of TQM and TPM paradigms on business performance. International Journal of Productivity and Performance Management, Vol 62 Iss: 1, pp. 66-84. doi. 10.1108/17410401311285309.

Kernerman English Multilingual Dictionary 2006-2013 K Dictionaries. n.d. Retrieved 5 November 2013, from http://www.thefreedictionary .com/tedious.

Loke S, DOWNE AG, SAMBASIVAN M \& KHALID K. 2012. A structural approach to integrating total quality management and knowledge management with supply chain learning. Journal of Business Economics and Management, 13(4), 776-800.

Merriam-Webster.Com. Merriam-Webster. n.d. Web. Accessed 5 November 2013 from http://www.merriamwebster.com/dictionary/complex.

Page C \& Meyer D. 2006. Applied research design for business and management. McGraw-Hill, Australia

Pycraft M, Singh H, Philela K, Slack N, Chambers S \& Johnston R. 2010. Operations Management. Cape Town: Pearson Education South Africa.

Ramwell, Brink, West. 2008. Conveyancing. UNISA Publishing. Pretoria.

Roghanian P, Rasli A \& Gheysari H. 2012. Productivity through effectiveness and efficiency in the banking industry. Procedia-Social and Behavioral Sciences, 40, 550-556.

Samson Se \& Spring M. 2012. Customer Roles in Service Supply Chains and Opportunities for Innovation. Journal of Supply Chain Management, 48:30-50. Doi: 10.1111/j.1745-493X.2012.03282x.

Slack N, Chambers S \& Johnston R. 2010. Operations Management. United Kingdom: Pearson Education Limited.

The Free Dictionary. n.d. Retrieved 5 November 2013 from http://www.thefreedictionary.com/cumbersome.

Winter M \& Knemeyer AM. 2013. Exploring the integration of sustainability and supply chain management: Current state and opportunities for future inquiry. International Journal of Physical Distribution \& Logistics Management. Vol 43 Iss:1, pp. 18-38. 